DOI https://doi.org/10.15589/znp2020.4(482).13 УДК 005.8

\title{
FORMATION OF MONETARY PARAMETERS OF THE ECOLOGISTICS SYSTEM PROJECT LIFE CYCLE
}

\section{ФОРМУВАННЯ ГРОШОВИХ ПАРАМЕТРІВ ЖИТТЕВОГО ЦИКЛУ ПРОЕКТУ ЕКОЛОГІСТИЧНОЇ СИСТЕМИ}

\author{
Tetiana A. Kovtun \\ teta.kovtun@gmail.com \\ ORCID: 0000-0002-5410-4783
}

\author{
T. А. Ковтун, \\ канд. техн. наук, доцент
}

\author{
Odesa National Maritime University, Odesa \\ Одеський наџіональний морський університет, м. Одеса
}

\begin{abstract}
Changing the worldview of mankind and the transition to the concept of sustainable development require the application of modern approaches to project management of ecologistics systems that meet the requirements of reducing eco-destructive impact on the environment. The need to take into account and eliminate the negative consequences of the functioning of the ecologistics system has led to the need to extend the life cycle of the project through the introduction of additional environmentally-oriented phases. Changing the composition of the life cycle affects its object, time and monetary characteristics.

The purpose of the article is to determine the features of the formation of monetary parameters of the ecological system project life cycle. To achieve this goal, the following tasks have been solved: cash flows have been identified during the life cycle of the ecologistics system project; the mechanism of influence on time parameters of a ecologistics system project life cycle is developed; calculation formulas for determining the cash flows of the project corresponding to the stages, time intervals and the entire life cycle of the project are presented.

The article uses the tools of project management methodology to determine the cash flows generated during the project life cycle. The object of research is the project of the ecologistics system, the subject-models and methods of managing the cost and time of the project.

The obtained results reflect the relationship between time and monetary parameters of the ecological system project. The presence of this dependence allowed developing of a mechanism for the formation of monetary characteristics of the project, which takes into account two options for determining the duration of the project life cycle (strictly and not strictly defined). Depending on the ability to influence the duration of the project life cycle, it is envisaged to apply situational or compensatory changes in the duration of the time stages, which will affect the value of cash flows of the project. The using of the calculation formulas presented in the article allows determining of the cash flows for stages, time intervals and life cycle for options strictly for non-strict determination of the life cycle duration of the ecologistics system project. The proposed mechanism for determining the monetary parameters of the project can be used to assess the effectiveness of the project environmental system.
\end{abstract}

Key words: ecologistics system; project life cycle; time and monetary parameters of the project; cash flow.

\begin{abstract}
Анотація. Зміна світогляду людства та перехід до концепції сталого розвитку потребують застосування сучасних підходів до управління проєктами екологістичних систем, що відповідають вимогам зменшення екодеструктивного впливу на довкілля. Необхідність врахування та ліквідації негативних наслідків функціонування екологістичної системи призвела до потреби подовження життєвого циклу проєкту шляхом введення додаткових еколого-орієнтованих фаз. Зміна складу життєвого циклу впливає на його об'єктні, часові та грошові характеристики.

Мета статті полягає у визначенні особливостей формування грошових параметрів життєвого циклу проєкту екологістичної системи. Для досягнення поставленої мети розв'язано такі завдання: визначено потоки грошових коштів протягом життєвого циклу проєкту екологістичної системи; розроблено механізм впливу на часові параметри життєвого циклу проєкту екологістичної системи; представлено розрахункові формули для визначення потоків грошових коштів проєкту, що відповідають етапам, часовим інтервалам і всьому життєвому циклу проєкту.

У статті застосовано інструментарій методології управління проєктами для визначення грошових потоків, що генеруються протягом життєвого циклу проєкту. Об'єктом дослідження є проєкт екологістичної системи, пред-
\end{abstract}


метом - моделі та методи управління вартістю та часом проєкту. Отримані результати відображають залежність між часовими та грошовими параметрами проєкту екологістичної системи. Наявність цієї залежності дала змогу розробити механізм формування грошових характеристик проєкту, що враховує два варіанти визначення тривалості життєвого циклу проєкту (суворо та не суворо визначену). Залежно від можливості впливати на тривалість життєвого циклу проєкту передбачається застосування ситуативних або компенсаційних змін тривалості часових етапів, що вплине на значення потоків грошових коштів проєкту. Застосування представлених у статті розрахункових формул дає змогу визначити потоки грошових коштів для етапів, часових інтервалів і життєвого циклу для варіантів суворого та не суворого визначення тривалості життєвого циклу проєкту екологістичної системи. Запропонований механізм визначення грошових параметрів проєкту може бути застосований під час оцінювання ефективності проєкту екологістичної системи.

Ключові слова: екологістична система; життєвий цикл проєкту; часові та грошові параметри проєкту; потік грошових коштів.

\section{ПОСТАНОВКА ЗАДАЧІ}

Врахування сучасних тенденцій розвитку людства на основі концепції сталого розвитку, спрямованих на збереження гідних умов існування наступним поколінням, потребує екологізації всіх сфер життя людини. Досягти зменшення екодеструктивного впливу господарської діяльності на довкілля можливо шляхом урахування екологічних аспектів під час проєктування та функціонування економічних систем, зокрема логістичних. Запобігання та ліквідація наслідків негативного екодеструктивного впливу на довкілля потребує застосування сучасних підходів, зокрема проєктного, до управління екологістичними системами.

\section{АНАЛІЗ ОСТАННІХ ДОСЛІДЖЕНЬ І ПУБЛІКАЦЙ}

Життєвий цикл є одним з основних понять методології управління проєктами. Відповідно до A Guide to the Project Management Body of Knowledge (PMBoK) під життєвим циклом (ЖЦ) розуміють період часу від початку до завершення проєкту [1].

Проєктний підхід передбачає поділ ЖЦ проєкту на фази, що характеризуються отриманням певного продукту. Фази проєкту можуть відрізнятися не тільки кількісно, але і якісно - за однакової назви фази в різних прикладних сферах можуть мати різне змістове навантаження. Навіть в одній прикладній сфері проєкти можуть відрізнятися за кількістю та тривалістю фаз ЖЦ [2]. ЖЦ проєкту (його тривалість, виділення окремих фаз та етапів) значною мірою залежать від характеристик самого проєкту (сфери застосування, масштабів, складності тощо).

Щораз більша важливість проблеми захисту навколишнього середовища і можливих впливів, пов'язаних із продукцією, що виготовляється та споживається, потребує подовження ЖЦ шляхом додавання еколого-орієнтованих фаз (етапів, стадій). Відповідно до [3] стадії ЖЦ повинні передбачати придбання сировини, проєктування, виробництво, транспортування/постачання, застосування, переробку після втрати придатності й остаточну утилізацію. У [4] під ЖЦ розуміють послідовні та взаємопов'язані стадії продукції (або послуг) від закупівлі сировини або виробництва з природних ресурсів до утилізації. У [5] оцінка ЖЦ передбачає розгляд усього ЖЦ продукту - від видобутку сировини та його придбання, зокрема виробництва енергії, матеріалу й виготовлення, до застосування продукту й наступного припинення його використання та остаточної утилізації.

Зміна поглядів на тривалість і склад фаз ЖЦ впливає на процес формування параметрів проєкту - специфічних характеристик, від управління якими залежить успіх проєкту. Важливість управління часом і вартістю проєкту підтверджується винесенням цих питань в окремі галузі знань методології управління проєктами [1].

Дослідження об'єктних, часових, грошових параметрів проєкту проводиться в роботах сучасних науковців. У [6] запропоновано застосування генетичного підходу до формування об'єктних і грошових характеристик продуктів проєкту. Оптимізувати часові параметри проєкту, спираючись на параметри продуктів проєкту, пропонуються в роботі [7]. Обгрунтовуються об'єктні та часові параметри проєкту у [8]. На необхідності управління часовими характеристиками фаз ЖЦ проєкту наполягають автори в [9]. У дослідженнях [10-13] питання управління часом проєкту розглядаються на рівні дослідження формування розкладу робіт проєкту. На врахуванні обмежених ресурсів під час формування параметрів проєкту зосереджують увагу дослідники в роботах [14-17].

\section{ВІДОКРЕМЛЕННЯ НЕ ВИРІШЕНИХ РАНІШЕ ЧАСТИН ЗАГАЛЬНОЇ ПРОБЛЕМИ}

Обгрунтовані потребами сьогодення зміни в ЖЦ проєктів екологістичних систем (ЕЛС) шляхом введення еколого-орієнтованих фаз потребують дослідження змін у формуванні об'єктних, часових і грошових параметрів, що характеризують продукти проєкту. Сучасні роботи, у яких висвітлюються питання формування параметрів проєктів, не враховують специфічних особливостей цієї категорії проєктів, що потребують дослідження. 


\section{МЕТА ДОСЛІДЖЕННЯ}

Визначити особливості формування грошових параметрів ЖЦ проєкту екологістичної системи. Для досягнення поставленої мети потрібно розв'язати такі завдання:

- визначити потоки грошових коштів протягом ЖЦ проєкту екологістичної системи;

- розробити механізм впливу на часові параметри ЖЦ проєкту екологістичної системи;

- представити розрахункові формули для визначення потоків грошових коштів проєкту, що відповідають етапам, часовим інтервалам і ЖЦ проєкту.

\section{МЕТОДИ, ОБ'ЄКТ ТА ПРЕДМЕТ ДОСЛІДЖЕННЯ}

У статті застосовано інструментарій методології управління проєктами для визначення грошових потоків, що генеруються протягом життєвого циклу проєкту. Об'єктом дослідження є проєкт екологістичної системи, предметом - моделі та методи управління вартістю та часом проєкту.

\section{ОСНОВНИЙ МАТЕРІАЛ}

ЖЦ проєкту ЕЛС пропонується поділяти на такі фази: передінвестиційну (pre-investment phase, P), інвестиційну (investment phase, I), експлуатаційну (operational phase, O), регенеративну (regenerative phase, $R$ ), ревіталізаційну (revitalization phase, V) [2].

У проєктах ЕЛС фази ЖЦ можуть як мати послідовний перебіг одна за одною (наприклад, інвестиційна фаза настає після завершення передінвестиційної фази), так і перекриватися (наприклад, регенеративна фаза починається до завершення експлуатаційної фази, коли продукт від кінцевого споживача надходить у зворотний потік матеріальних ресурсів, а ревіталізаційна фаза починається разом з інвестиційною та триває майже до закінчення проєкту).
Фази ЖЦ проєкту ЕЛС утворюють множину фаз проєктів $C^{f},(f=\overline{1 ; F})$ Етапи (стадії) фаз ЖЦ проєкту утворюють множину $S^{f j}, f(f=\overline{1 ; F})$ - фаза проєкту, $j(j=\overline{1 ; J})$ - етап фази. Етапам фаз ЖЦ проєкту ЕЛС відповідають часові інтервали $\left[t_{i} ; t_{i+1}\right](i=\overline{1 ; I-1})$, де $t_{i}$ - початок, $t_{i+1}$ - закінчення часового інтервалу тривалості етапу фази проєкту, які є віховими подіями. Протягом ЖЦ проєкту ЕЛС пропонується виділяти такі віхові події:

$t_{0}$ - початок проєкту, передінвестиційної фази;

$t_{1}$ - початок інвестиційної та ревіталізаційної фаз, закінчення передінвестиційної фази;

$t_{2}$ - початок експлуатаційної фази, закінчення інвестиційної фази;

$t_{3}$ - початок регенеративної фази;

$t_{4}$ - закінчення експлуатаційної фази;

$t_{5}$ - закінчення регенеративної фази;

$t_{6}$ - закінчення проєкту, ревіталізаційної фази.

Отже, ЖЦ ЕЛС передбачає множину $T I^{i}$, $(i=\overline{1 ; I-1})$ часових інтервалів $\left[t_{i} ; t_{i+1}\right]$ - періодів часу, початком і завершенням яких $є$ віхові події, яким відповідають початок або завершення фази (етапу) проєкту, що характеризуються отриманням певного результату.

До ЖЦ проєкту ЕЛС входять фази, які відрізняються кількістю етапів в їхньому складі:

перша, передінвестиційна фаза $-P_{[0 ; 1]}^{11}$,

друга, інвестиційна фаза - $I_{[n: 21]}^{21}$,

третя, експлуатаційна фаза $-O_{[2 ; ; 3]}^{31}, O_{[3 ; ; 4]}^{32}$,

четверта, регенеративна фаза - $R_{[5 ; ; 4]}^{41}, R_{[4 ; ; 5]}^{42}$,

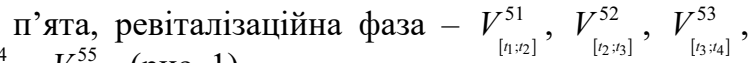
$V_{[4 ;: 5]}^{54}, V_{[5 ; 6]}^{55}$ (рис. 1).

Етапи ЖЦ проєкту ЕЛС повинні завершуватись отриманням проміжного результату - продукту фази

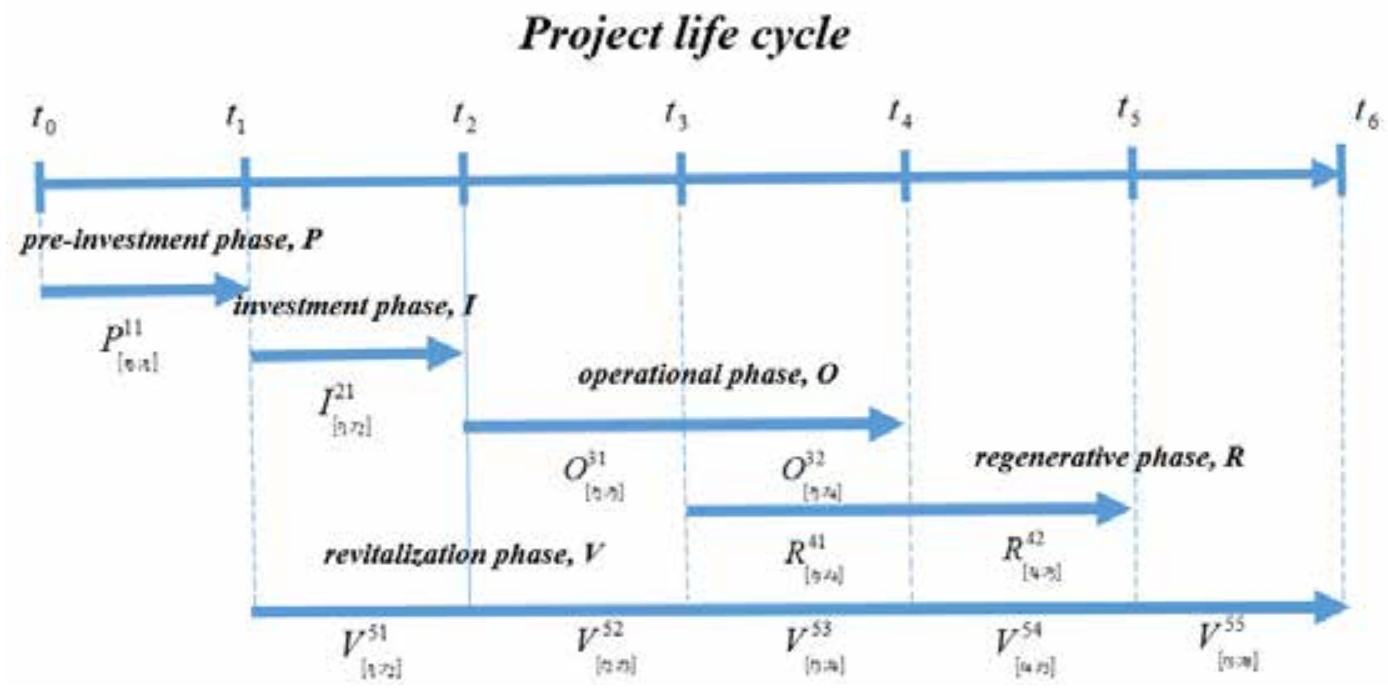

Рис. 1. Життєвий цикл проєкту екологістичної системи 
(етапу) проєкту, який належить до множини продуктів проєкту $R_{\left[i_{i}: i_{i+1}\right]}^{f j}, f(f=\overline{1 ; F}), j(j=\overline{1 ; J}),(i=\overline{1 ; I-1})$ (табл. 1).

ЖЦ проєкту ЕЛС характеризується часовими й вартісними параметрами. Основними вартісними показниками є потоки грошових коштів проєкту $C F_{\left[i_{i} ; i_{i+1}\right]}^{f j}, \quad f(f=\overline{1 ; F}), \quad j(j=\overline{1 ; J}), \quad(i=\overline{1 ; I-1})$, які формуються 3 притоків $I F_{\left[i_{i} ; i_{i+1}\right]}^{f j}$ та відтоків $O F_{\left[i_{i} ; i_{i+1}\right]}^{f j}$ грошових коштів, значення яких відрізняються на різних часових інтервалах та етапах ЖЦ проєкту.

Отже, для характеристики ЖЦ проєкту ЕЛС формуються такі множини:

- множина фаз ЖЦ проєкту

$C^{f}=\{P ; I ; O ; R ; V\} ;$

- множина часових інтервалів ЖЦ проєкту

$T I^{i}=\left\{\left[t_{0} ; t_{1}\right] ;\left[t_{1} ; t_{2}\right] ;\left[t_{2} ; t_{3}\right] ;\left[t_{3} ; t_{4}\right] ;\left[t_{4} ; t_{5}\right] ;\left[t_{5} ; t_{6}\right]\right\} ;$

- множина етапів фаз ЖЦ проєкту

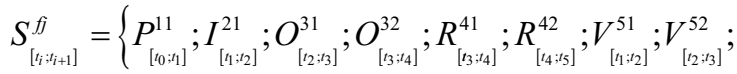
$\left.V_{[3 ; ; 4]}^{53} ; V_{\left[4_{4} ; 5\right]}^{54} ; V_{\left[5 ; t_{6}\right]}^{55}\right\}$;

- множина результатів етапів - проміжних продуктів проєкту

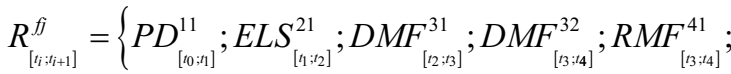

$$
\begin{aligned}
& \left.R M F_{\left[t_{4} ; t_{1}\right]}^{42} ; R V_{\left[t_{1} ; t_{2}\right]}^{51} ; R V_{\left[t_{2} ; t_{3}\right]}^{52} ; R V_{\left[t_{3} ; 4\right]}^{53} ; R V_{\left[t_{4} ; 5\right]}^{54} ; R V_{\left[t_{5} ; 6_{6}\right]}^{55}\right\} \text {; }
\end{aligned}
$$

- множина потоків грошових коштів, які генерують проміжні продукти проєкту

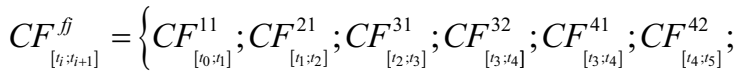

$$
\left.C F_{[1 ; ; 2]}^{51} ; C F_{\left[t_{2} ; t_{3}\right]}^{52} ; C F_{\left[t_{3} ; 4\right]}^{53} ; C F_{\left[4_{4} ; t_{3}\right]}^{54} ; C F_{\left[t_{5} ; t_{6}\right]}^{55}\right\} .
$$

Потоки грошових коштів $C F_{\left[f_{i} ; i_{1+1}\right]}^{f j}$ різняться протягом ЖЦ проєкту ЕЛС та набувають позитивних і негативних значень залежно від етапу проєкту (рис. 2).

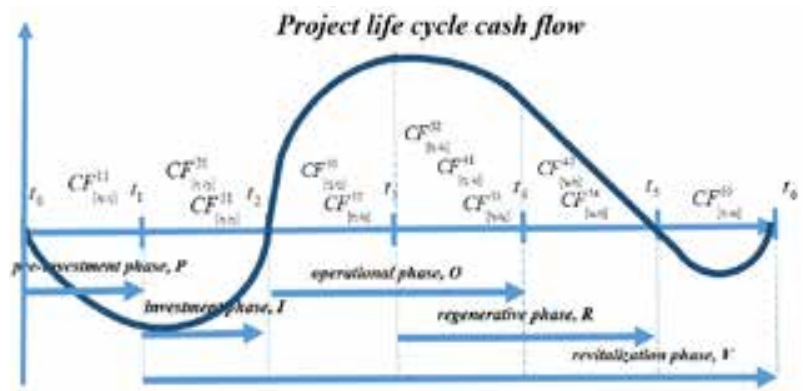

Рис. 2. Потоки грошових коштів протягом ЖЦ проєкту ЕЛС

Відмінною рисою проєктів ЕЛС $€$ наявність додаткових еколого-орієнтованих фаз ЖЦ: регенеративної та ревіталізаційної. Додавання цих фаз до ЖЦ вносить певні зміни у формування грошових потоків проєкту - збільшується кількість фаз, на яких формуються притоки грошових коштів завдяки регенеративній фазі, та збільшується кількість фаз, протягом яких утворюються відтоки грошових коштів завдяки регенеративній і ревіталізаційній фазам (табл. 2).

Отже, крім множини потоків грошових коштів проєкту $C F_{\left[i_{i} ; i_{1+1}\right]}^{f j}$ формуються такі множини вартісних

\begin{tabular}{|c|c|c|}
\hline Часовий інтервал & Етап фази ЖЦ проєкту ЕЛС & Проміжний результат - продукт фази (етапу) проскту \\
\hline$\left[t_{0} ; t_{1}\right]$ & передінвестиційна фаза, $P_{[0 ;: t]}^{11}$ & документально оформлений проєкт ЕЛС, $P D_{\left[t_{0}: t\right]}^{11}$ \\
\hline \multirow{2}{*}[t_{1};t_{2}]{} & інвестиційна фаза, $I_{\left[n_{1} ; 2\right]}^{21}$ & ЕЛС, $E L S_{[n ; ; 2]}^{21}$ \\
\hline & етап ревіталізаційної фази, $V_{\left[\eta_{1} ; x_{2}\right]}^{51}$ & ревіталізація наслідків створення ЕЛС, $R V_{[1: ; 2]}^{51}$ \\
\hline \multirow[b]{2}{*}[t_{2};t_{3}]{} & етап експлуатаційної фази, $O_{\left[z_{2} ; 3\right]}^{31}$ & ЕЛП (прямий матеріальний потік), $D M F_{\left[{ }_{2} ; t_{3}\right]}^{31}$ \\
\hline & етап ревіталізаційної фази, $V_{[2 ; 2 ; 3]}^{52}$ & $\begin{array}{l}\text { ревіталізація наслідків ЕЛП (прямого матеріального потоку), } \\
\qquad R V_{\left[{ }_{2} ; 3_{3}\right]}^{52} \\
\end{array}$ \\
\hline \multirow{3}{*}[t_{3};t_{4}]{} & етап експлуатаційної фази, $O_{[3 ;: 4]}^{32}$ & ЕЛП (прямий матеріальний потік), $D M F_{[3 ; ; 4]}^{32}$ \\
\hline & етап регенеративної фази, $R_{[3 ; 4]}^{41}$ & ЕЛП (зворотний матеріальний потік), $R M F_{\left[r_{3} ; 4\right]}^{41}$ \\
\hline & етап ревіталізаційної фази, $V_{[3 ; 4]}^{53}$ & $\begin{array}{l}\text { ревіталізація наслідків ЕЛП (прямого та зворотного } \\
\text { матеріальних потоків), } R V_{[3 ;, 4]}^{53} \\
\end{array}$ \\
\hline \multirow[b]{2}{*}[t_{4};t_{5}]{} & етап регенеративної фази, $R_{[4 ; ; 5]}^{42}$ & ЕЛП (зворотний матеріальний потік), $R M F_{[4 ; 45]}^{42}$ \\
\hline & етап ревіталізаційної фази, $V_{[4 ;: 5]}^{54}$ & $\begin{array}{c}\text { ревіталізація наслідків ЕЛП (зворотного матеріального потоку), } \\
\qquad R V_{[4 ;: 5]}^{54} \\
\end{array}$ \\
\hline$\left[t_{5} ; t_{6}\right]$ & етап ревіталізаційної фази, $V_{[5 ;: 6]}^{55}$ & ревіталізація наслідків проєкту ЕЛС, $R V_{\left[s_{5 ; 6} ; 6\right]}^{55}$ \\
\hline
\end{tabular}
показників ЖЦ проєкту ЕЛС:

Таблиця 1. Результати етапів ЖЦ проєкту ЕЛС 
Таблиця 2. Грошові потоки етапів ЖЦ проєкту ЕЛС

\begin{tabular}{|c|c|c|c|c|c|}
\hline \multirow[b]{2}{*}{ Часовий інтервал } & \multirow{2}{*}{$\begin{array}{c}\text { Етап фази ЖЦ } \\
\text { проскту ЕЛС }\end{array}$} & \multirow{2}{*}{$\begin{array}{l}\text { Продукт фази } \\
\text { (етапу) проскту }\end{array}$} & \multirow{2}{*}{$\begin{array}{c}\text { Потоки } \\
\text { грошових коштів }\end{array}$} & \multicolumn{2}{|c|}{ Значення } \\
\hline & & & & $\begin{array}{c}\text { притоків } \\
\text { грошових коштів }\end{array}$ & $\begin{array}{c}\text { відтоків } \\
\text { грошових коштів }\end{array}$ \\
\hline$\left[t_{0} ; t_{1}\right]$ & $P_{\left[{ }^{0} ; t_{1}\right]}^{11}$ & $P D_{\left[t_{0} ; t\right]}^{11}$ & $C F_{\left[t_{0} ; t_{1}\right]}^{11}$ & $I F_{\left[t_{0} ; t_{1}\right]}^{11}=0$ & $O F_{\left[0^{\prime} ; r_{1}\right]}^{11}<0$ \\
\hline \multirow{2}{*}[t_{1};t_{2}]{} & $I_{\left[l_{1} ; 2_{2}\right]}^{21}$ & $E L S_{\left[t_{1}: t_{2}\right]}^{21}$ & $C F_{\left[l_{1} ; 2_{2}\right]}^{21}$ & $I F_{\left[l_{1} ; t_{2}\right]}^{21}=0$ & $O F_{\left[\left[_{1} ; r_{2}\right]\right.}^{21}<0$ \\
\hline & $V_{\left[l_{1} ; 2_{2}\right]}^{51}$ & $R V_{\left[l_{1} ; 2_{2}\right]}^{51}$ & $C F_{\left[\left[_{1} ; 2_{2}\right]\right.}^{51}$ & $I F_{\left[l_{1} ; t_{2}\right]}^{51}=0$ & $O F_{\left[\left[_{1} ; r_{2}\right]\right.}^{51}<0$ \\
\hline \multirow{2}{*}[t_{2};t_{3}]{} & $O_{\left[\left[_{2} ; 3_{3}\right]\right.}^{31}$ & $D M F_{\left[t_{2} ; t_{3}\right]}^{31}$ & $C F_{\left[t_{2} ; t_{3}\right]}^{31}$ & $I F_{\left[t_{2} ; t_{3}\right]}^{31}>0$ & $O F_{\left[l_{2} ; t_{3}\right]}^{31}<0$ \\
\hline & $V_{\left[t_{2} ; t_{3}\right]}^{52}$ & $R V_{\left[t_{2} ; 3_{3}\right]}^{52}$ & $C F_{\left[t_{2} ; t_{3}\right]}^{52}$ & $I F_{\left[t_{2} ; t_{3}\right]}^{52}=0$ & $O F_{\left[\left[_{2} ; z_{3}\right]\right.}^{52}<0$ \\
\hline \multirow{3}{*}[t_{3};t_{4}]{} & $O_{[3 ; 44]}^{32}$ & $D M F_{\left[{ }_{[3 ;} ; 4\right]}^{32}$ & $C F_{[13 ; 4]}^{32}$ & $I F_{\left[r_{3} ; 4\right]}^{32}>0$ & $O F_{[[3 ; 4]}^{32}<0$ \\
\hline & $R_{\left[3 ; 4_{4}\right]}^{41}$ & $R M F_{\left[\left[_{3} ; t_{4}\right]\right.}^{41}$ & $C F_{\left[\left[_{3} ; 4\right]\right.}^{41}$ & $I F_{\left[r_{3} ; t_{4}\right]}^{41}>0$ & $O F_{\left[r_{3} ; 4_{4}\right]}^{41}<0$ \\
\hline & $V_{\left[r_{3} ; 4\right]}^{53}$ & $R V_{\left[r_{3} ; 4\right]}^{53}$ & $C F_{\left[r_{3} ; 4\right]}^{53}$ & $I F_{\left[3_{3} ; 4\right]}^{53}=0$ & $O F_{\left[\left[_{3} ; 4_{4}\right]\right.}^{53}<0$ \\
\hline \multirow{2}{*}[t_{4};t_{5}]{} & $R_{[4 ; ; 5]}^{42}$ & $R M F_{\left[t_{4} ; t_{5}\right]}^{42}$ & $C F_{\left[{ }^{4} ; t_{5}\right]}^{42}$ & $I F_{\left[t_{4} ; t_{5}\right]}^{42}>0$ & $O F_{\left[{ }^{\left[4 ; t_{5}\right]}\right.}^{42}<0$ \\
\hline & $V_{\left[t_{4} ; 5\right]}^{54}$ & $R V_{\left[t_{4} ; t_{5}\right]}^{54}$ & $C F_{\left[t_{4} ; t_{5}\right]}^{54}$ & $I F_{\left[{ }^{4} ; t_{5}\right]}^{54}=0$ & $O F_{\left[t_{4} ; t_{5}\right]}^{54}<0$ \\
\hline$\left[t_{5} ; t_{6}\right]$ & $V_{[5 ; ; 6]}^{55}$ & $R V_{[t 5 ; 6]}^{55}$ & $C F_{[t 5 ; 6]}^{56}$ & $I F_{\left[t_{5} ; 7_{6}\right]}^{56}=0$ & $O F_{[t 5 ; 6]}^{56}<0$ \\
\hline
\end{tabular}

- множина відтоків грошових коштів

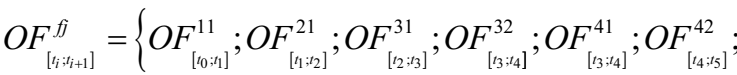

$\left.O F_{\left[t_{1} ; t_{2}\right]}^{51} ; O F_{\left[t_{2} ; r_{3}\right]}^{52} ; O F_{\left[l_{3} ; t_{4}\right]}^{53} ; O F_{\left[t_{4} ; t_{5}\right]}^{54} ; O F_{[5 ; ; 6]}^{55}\right\}$;

- множина притоків грошових коштів

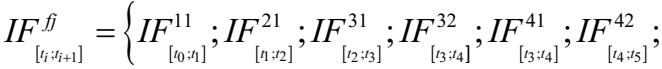

$$
\begin{aligned}
& \left.I F_{[1 ;: 2]}^{51} ; I F_{[2 ; 13]}^{52} ; I F_{[3 ; ; 4]}^{53} ; I F_{[4 ; ; 5]}^{54} ; I F_{[5 ; 76]}^{55}\right\} \text {; }
\end{aligned}
$$

Для кожного часового інтервалу $\left[t_{i} ; t_{i+1}\right]$, $(i=\overline{0 ; I-1})$ ЖЦ можна розрахувати значення потоків грошових коштів (табл. 3). Водночас потрібно враховувати потоки грошових коштів, що генеруються під час створення продуктів фаз проєкту на певних часових інтервалах, як представлено у формулі

$$
C F_{\left[t_{i} ; i_{i+1}\right]}=\sum_{f=1}^{F} \sum_{j=1}^{J} C F_{\left[t_{i} ; t_{i+1}\right]}^{f j}=\int_{t_{i}}^{t_{i+1}} i f(t) d t+\int_{t_{i}}^{t_{i+1}} o f(t) d t,
$$

де $\int_{t_{i}}^{t_{i+1}} i f(t) d t-$ притоки грошових коштів, що генеруються протягом часового інтервалу $\left[t_{i} ; t_{i+1}\right]$;

$\int_{t}^{t_{i+1}} o f(t) d t$ - відтоки грошових коштів, що генеруються протягом часового інтервалу $\left[t_{i} ; t_{i+1}\right]$.
Загальні потоки грошових коштів протягом ЖЦ проєкту ЕЛС розраховуються за формулою

$$
C F_{L C}=\sum_{i=0}^{I-1} \sum_{f=1}^{F} \sum_{j=1}^{J} C F_{\left[t_{i} ; t_{i+1}\right]}^{f j}=\int_{t_{i}}^{t_{I-1}} i f(t) d t+\int_{t_{i}}^{t_{I-1}} o f(t) d t,
$$

де $\int_{t_{i}}^{t_{t-1}} i f(t) d t-$ притоки грошових коштів, що генеруються протягом ЖЦ проєкту;

$\int_{t_{i}}^{t_{I-1}} o f(t) d t$ - відтоки грошових коштів, що генеруються протягом ЖЦ проєкту.

Відтоки грошових коштів мають значення, що не дорівнюють нулю, протягом усіх часових інтервалів проєкту. На відміну від них, притоки грошових коштів генеруються тільки протягом експлуатаційної та регенеративної фаз проєкту. У такому разі загальне значення потоку грошових коштів, які заплановано отримати протягом проєкту, визначається як сума потоків і відтоків грошових коштів на певних часових інтервалах проєкту та розраховується за формулою

$$
C F_{L C}^{\text {plan }}=I F_{L C}^{\text {plan }}+O F_{L C}^{\text {plan }},
$$

де $I F_{L C}^{\text {plan }}$ та $O F_{L C}^{\text {plan }}$ - заплановані значення притоків і відтоків грошових коштів відповідно, $I F_{L C}^{\text {plan }} \geq 0$ та $O F_{L C}^{\text {plan }}<0$. 
Таблиця 3. Формули для розрахунку потоків грошових коштів проєкту ЕЛС

\begin{tabular}{|c|c|c|}
\hline Часовий інтервал & Формула для розрахунку потоків грошових коштів & Номер формули \\
\hline$\left[t_{0} ; t_{1}\right]$ & $C F_{\left[r_{0} ; t\right]}=C F_{\left[r_{0}: t_{1}\right]}^{11}=\int_{0} c f(t) d t=\int_{0} i f(t) d t+\int_{0} o f(t) d t$ & (2) \\
\hline$\left[t_{1} ; t_{2}\right]$ & $\begin{array}{l}C F_{[1 ;: 2]}=C F_{[1 ;: 2]}^{21}+C F_{[1 ;: 2]}^{51}=\int_{1}^{2} c f^{21}(t) d t+\int_{1}^{2} c f^{51}(t) d t= \\
=\int_{1}^{2} i f^{21}(t) d t+\int_{1}^{2} o f^{21}(t) d t+\int_{1}^{2} i f^{51}(t) d t+\int_{1}^{2} o f^{51}(t) d t\end{array}$ & (3) \\
\hline$\left[t_{2} ; t_{3}\right]$ & $\begin{array}{l}C F_{[2 ;: 3]}=C F_{[2 ;: 3]}^{31}+C F_{\left[2 ; z_{3}\right]}^{52}=\int_{2} c f^{31}(t) d t+\int_{2} c f^{52}(t) d t= \\
=\int_{2}^{3} i f^{31}(t) d t+\int_{2}^{3} i f^{31}(t) d t+\int_{2}^{3} i f^{52}(t) d t+\int_{2}^{3} o f^{52}(t) d t\end{array}$ & (4) \\
\hline$\left[t_{3} ; t_{4}\right]$ & $\begin{array}{l}C F_{[3 ; 4 ;]}=C F_{[3 ; 44]}^{32}+C F_{\left[\left[_{3} ; 4\right]\right.}^{41}+C F_{[3 ; ; 4]}^{53}=\int_{3}^{4} c f^{32}(t) d t+ \\
+\int_{3}^{4} c f^{41}(t) d t+\int_{3}^{4} c f^{53}(t) d t=\int_{3}^{4} i f^{32}(t) d t+\int_{3}^{4} o f^{32}(t) d t+ \\
+\int_{3}^{4} o f^{41}(t) d t+\int_{3}^{4} o f^{41}(t) d t+\int_{3}^{4} i f^{53}(t) d t+\int_{3}^{4} o f^{53}(t) d t\end{array}$ & (5) \\
\hline$\left[t_{4} ; t_{5}\right]$ & $\begin{array}{l}C F_{[4 ; ; 5]}=C F_{[4 ; ; 5]}^{42}+C F_{[4 ; ; 5]}^{54}=\int_{4}^{5} c f^{42}(t) d t+\int_{4}^{5} c f^{54}(t) d t= \\
=\int_{4}^{5} i f^{42}(t) d t+\int_{4}^{5} o f^{42}(t) d t+\int_{4}^{5} i f^{54}(t) d t+\int_{4}^{5} o f^{54}(t) d t\end{array}$ & (6) \\
\hline$\left[t_{5} ; t_{6}\right]$ & $C F_{\left[5 ; t^{\prime}\right]}=C F_{\left[5_{5} ; t^{2}\right]}^{56}=\int_{5}^{0} c f^{56}(t) d t=\int_{5}^{0} i f^{56}(t) d t+\int_{5}^{0} o f^{56}(t) d t$ & (7) \\
\hline
\end{tabular}

Заплановані значення вартісних показників ЖЦ проєкту ЕЛС розраховуються за формулами:

- притоки грошових коштів

$$
I F_{L C}^{\text {plan }}=\int_{t_{2}}^{t_{5}} i f(t) d t=\int_{t_{2}}^{t_{3}} i f(t) d t+\int_{t_{3}}^{t_{4}} i f(t) d t+\int_{t_{4}}^{t_{5}} i f(t) d t,
$$

- відтоки грошових коштів

$$
\begin{gathered}
O F_{L C}^{\text {plan }}=\int_{t_{0}}^{t_{6}} o f(t) d t=\int_{t_{0}}^{t_{1}} o f(t) d t+\int_{t_{1}}^{t_{2}} o f(t) d t+ \\
+\int_{t_{2}}^{t_{3}} o f(t) d t+\int_{t_{3}}^{t_{4}} o f(t) d t+\int_{t_{4}}^{t_{5}} o f(t) d t+\int_{t_{5}}^{t_{6}} o f(t) d t .
\end{gathered}
$$

Тривалість етапів і фаз ЖЦ проєкту ЕЛС може змінюватися під впливом внутрішніх і зовнішніх факторів. $Є$ два можливих підходи до управління тривалістю ЖЦ проєкту ЕЛС:

1. Тривалість ЖЦ проєкту може змінюватися, термін закінчення проєкту не є суворо визначеним. Тоді зміни у тривалості окремих фаз позначаться на фактичній загальній тривалості ЖЦ проєкту $T_{L C}^{\text {fact }}$.

2. Тривалість ЖЦ $T_{L C}^{\text {plan }} \epsilon$ визначеною, проєкт повинен бути завершений у суворого визначений тер-
Таблиця 4. Варіанти тривалості ЖЦ проєкту ЕЛС

\begin{tabular}{|c|c|c|}
\hline Часова характеристика & \multicolumn{2}{|c|}{ Стан характеристик } \\
\cline { 2 - 3 } проєкту & Варіант 1 & Варіант 2 \\
\hline Плановий термін & & \\
завершення проєкту, & $T_{L C}^{\text {plan }} \neq$ const & $T_{L C}^{\text {plan }}=$ const \\
$T_{L C}^{\text {plan }}$ & & \\
\hline Фактичний термін & & \\
завершення проєкту, & $T_{L C}^{\text {fact }} \neq T_{L C}^{\text {plan }}$ & $T_{L C}^{f a c t}=T_{L C}^{\text {plan }}$ \\
$T_{L C}^{\text {fact }}$ & & \\
\hline
\end{tabular}

мін. У цьому разі у випадку зміни тривалості попередньої фази повинна змінюватися тривалість наступної фази або наступних фаз для збереження загальної тривалості ЖЦ проєкту (табл. 4).

Залежно від вибору варіанта управління вартістю ЖЦ проєкту, визначаються вартісні параметри проєкту (табл. 5).

Варіант 1. Тривалість ЖЦ проєкту ЕЛС не суворо визначена

У разі ситуаційних змін тривалості запланованого часового інтервалу $\left[t_{i} ; t_{i+1}\right]$ проєкту на фактичний $\left[t_{i} ; t_{i+1}^{\prime}\right]$ зміни відбудуться у значенні потоків грошо- 
Таблиця 5. Грошові потоки за різних варіантів тривалості ЖЦ проєкту ЕЛС

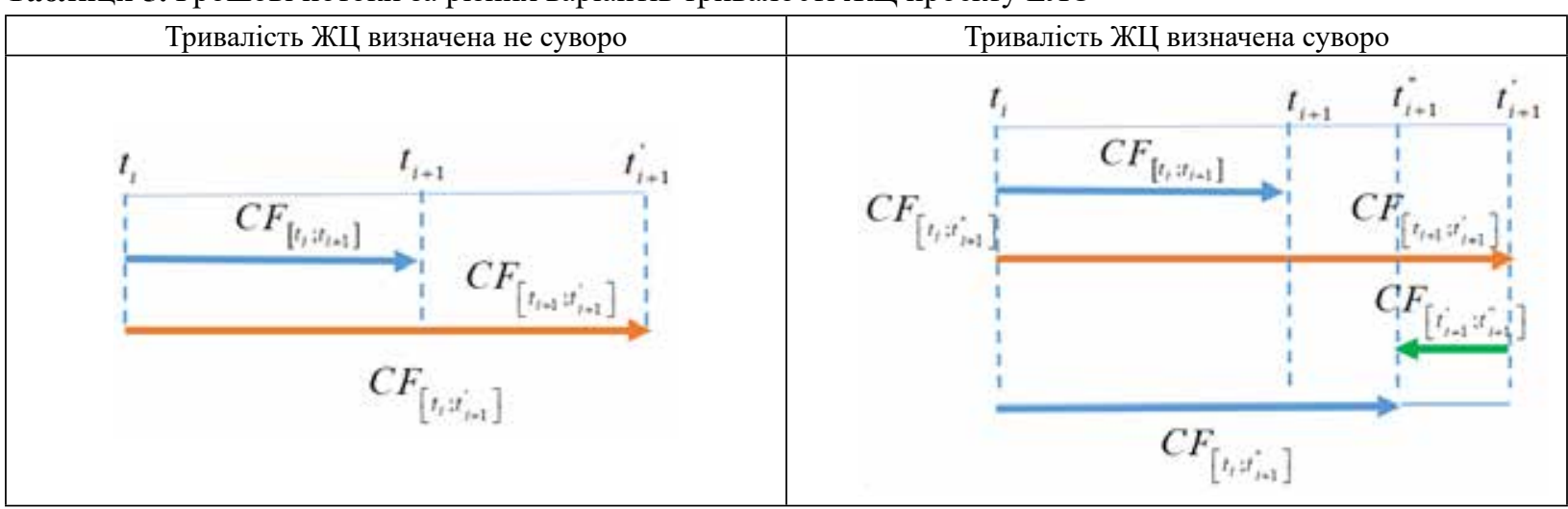

вих коштів, які генеруються протягом етапів проєкту $C F_{\left[t_{i} ; t_{i+1}\right]}^{f j}$ та часових інтервалів $C F_{\left[t_{i} ; i_{i+1}\right]}$ (табл. 5). На часовому інтервалі $\left[t_{i+1} ; t_{i+1}^{\prime}\right]$ генеруються притоки $I F_{\left[t_{i+1} ; i_{i+1}\right]}$ та відтоки $O F_{\left[t_{i+1} ; i_{i+1}\right]}$ грошових коштів, які створюють додатковий незапланований грошовий потік $C F_{\left[t_{i+1} ; i_{i+1}\right]}$

$$
C F_{\left[t_{i+1} ; i_{i+1}\right]}=\sum_{f=1}^{F} \sum_{j=1}^{J} C F_{\left[t_{i+1} ; i_{i+1}\right]}^{f j}=\int_{t_{i+1}}^{i_{i+1}} i f(t) d t+\int_{t_{i+1}}^{i_{i+1}} o f(t) d t,
$$

де $\int_{t_{i+1}}^{t_{i+1}} i f(t) d t-$ притоки грошових коштів, що генеруються протягом часового інтервалу $\left[t_{i+1} ; t_{i+1}^{\prime}\right]$;

$\int^{t_{i+1}} o f(t) d t$ - відтоки грошових коштів, що генеруЮться протягом часового інтервалу $\left[t_{i+1} ; t_{i+1}^{\prime}\right]$.

У разі зміни строків закінчення попереднього інтервалу $\left[t_{i} ; t_{i+1}^{\prime}\right]$ змінюються строки початку наступного інтервалу $\left[t_{i}^{\prime} ; t_{i+1}^{\prime}\right]$.

Загальна сума грошових коштів протягом усього ЖЦ проєкту ЕЛС розраховується за формулою

$$
C F_{L C}^{f a c t}=\sum_{i=0}^{I-1} \sum_{f=1}^{F} \sum_{j=1}^{J} C F_{\left[t_{i} ; i_{i+1}\right]}^{f f}=\int_{t_{i}}^{i_{I-1}} i f(t) d t+\int_{t_{i}}^{t_{I-1}} o f(t) d t,
$$

де $\int_{t_{i}}^{i_{t_{-1}}} i f(t) d t-$ притоки грошових коштів, що генеруються протягом ЖЦ проєкту;

$\int_{t_{i}}^{t_{t-1}} o f(t) d t$ - відтоки грошових коштів, що генеруються протягом ЖЦ проєкту.

Варіант 2. Тривалість ЖЦ проєкту ЕЛС суворо визначена

Розв'язується завдання стабілізації тривалості ЖЦ шляхом вжиття заходів щодо компенсації змін тривалостей етапів ЖЦ, що, зі свого боку, впливає на зміну тривалостей часових інтервалів, яким відповідають ці етапи. На реалізацію заходів щодо повер- нення тривалості запланованого часового інтервалу $\left[t_{i} ; t_{i+1}\right]$ з фактичного $\left[t_{i} ; t_{i+1}^{\prime}\right]$ до скоригованого $\left[t_{i} ; t_{i+1}\right]$ необхідно витратити певні грошові кошти, які визначаються як сума коштів, витрачених на коригування тривалостей кожного з етапів проєкту, що реалізуються протягом часового інтервалу $\left[t_{i} ; t_{i+1}\right]$

$$
C F_{\left[t_{i+1}^{\prime} ; t_{i+1}^{\prime}\right]}^{c o r}=\sum_{f=1}^{F} \sum_{j=1}^{J} C F_{\left[t_{i+1}^{\prime} i_{i+1}^{\prime}\right.}^{f j}=\int_{t_{i+1}^{\prime}}^{t_{i+1}} o f(t) d t,
$$

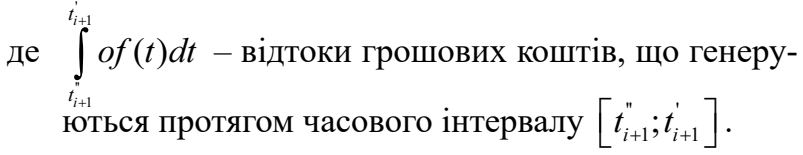

Вплив ситуаційних змін тривалості часового інтервалу $\left[t_{i} ; t_{i+1}\right]$ на $\left[t_{i} ; t_{i+1}^{\prime}\right]$ і компенсаційних змін $\left[t_{i+1}^{\prime \prime} ; t_{i+1}^{\prime}\right]$ на грошові потоки розраховується за формулою

$$
\begin{aligned}
& C F_{\left[t_{i} ; t_{i+1}\right]}^{f a c t}=\int_{t_{i}}^{t_{i+1}} c f(t) d t+\int_{t_{i+1}}^{t_{i+1}} c f(t) d t+ \\
& +\int_{t_{i+1}}^{t_{i+1}} c f(t) d t=\int_{t_{i}}^{t_{i+1}} i f(t) d t+\int_{t_{i}}^{t_{i+1}} o f(t) d t+, \\
& +\int_{t_{i+1}}^{i_{i+1}} i f(t) d t+\int_{t_{i+1}}^{t_{i+1}} o f(t) d t+\int_{t_{i+1}^{\prime}}^{i_{i+1}} o f(t) d t
\end{aligned}
$$

де $t_{i}$ - початок запланованого часового інтервалу $\left[t_{i} ; t_{i+1}\right]$,

$t_{i+1}$ - закінчення запланованого часового інтервалу $\left[t_{i} ; t_{i+1}\right]$,

$t_{i+1}^{\prime}$ - закінчення часового інтервалу $\left[t_{i} ; t_{i+1}^{\prime}\right]$ після ситуативних змін,

$t_{t+1}^{\prime \prime}$ - закінчення часового інтервалу $\left[t_{i} ; t_{i+1}^{\prime \prime}\right]$ після компенсаційних змін.

У разі зміни строків закінчення попереднього інтервалу $\left[t_{i} ; t_{i+1}^{\prime \prime}\right]$ змінюються строки початку наступного інтервалу $\left[t_{i}^{\prime \prime} ; t_{i+1}^{\prime \prime}\right]$. 
Загальна сума грошових коштів протягом усього ЖЦ проєкту ЕЛС розраховується за формулою

$$
C F_{L C}^{f a c t}=\sum_{i=0}^{I-1} \sum_{f=1}^{F} \sum_{j=1}^{J} C F_{\left[t_{i} ; t_{i+1}^{\prime \prime}\right]}^{f j}=\int_{t_{i}^{\prime}}^{t_{I-1}^{\prime \prime}} i f(t) d t+\int_{t_{i}^{\prime \prime}}^{t_{I-1}^{\prime \prime}} o f(t) d t
$$

$$
\begin{aligned}
& \text { де } \int_{t_{i}^{\prime}}^{t_{I-1}^{\prime \prime}} i f(t) d t-\text { притоки грошових коштів, що генеру- } \\
& \text { ються протягом ЖЦ проєкту; } \\
& \int_{t_{i}^{\prime \prime}}^{t_{t-1}^{\prime \prime}} o f(t) d t-\text { відтоки грошових коштів, що генеру- } \\
& \text { ються протягом ЖЦ проєкту. }
\end{aligned}
$$

\section{ОБГОВОРЕННЯ ОТРИМАНИХ РЕЗУЛЬТАТІВ}

Отримані результати відображають залежність між часовими та грошовими параметрами проєкту ЕЛС. Наявність цієї залежності дає змогу розробити механізм формування грошових характеристик проєкту, що враховує два варіанти визначення тривалості ЖЦ проєкту. Залежно від можливості впливати на тривалість ЖЦ проєкту ЕЛС передбачається застосування ситуативних змін або компенсаційних змін тривалості часових етапів, що вплине на значення потоків грошових коштів проєкту. Застосування представлених розрахункових формул дає змогу визначити потоки грошових коштів для етапів, часових інтерва- лів і всього ЖЦ для варіантів суворого на не суворого визначення тривалості ЖЦ проєкту ЕЛС.

\section{ВИСНОВКИ}

1. ЖЦ проєкту ЕЛС відрізняється від класичного ЖЦ проєкту наявністю еколого-орієнтованих фаз. До його складу входять передінвестиційна, інвестиційна, експлуатаційна, регенеративна та ревіталізаційна фази, між якими створюються послідовні й такі, що перекриваються, зв'язки.

2. ЖЦ проєкту ЕЛС та його складники: окремі етапи, фази, часові інтервали характеризуються часовими та грошовими характеристиками. Часові параметри можуть змінюватися під ситуативним впливом внутрішнього середовища та зовнішнього оточення проєкту. Визначено два можливих варіанти визначення тривалості ЖЦ проєкту, залежно від яких розроблено механізм формування часових параметрів. Механізмом передбачено ситуативні та компенсаційні зміни часових параметрів проєкту.

3. Зміна часових параметрів впливає на значення грошових характеристик проєкту. Для кожного 3 варіантів запропоновано розрахункові формули для визначення потоків грошових коштів для етапів, часових інтервалів та ЖЦ проєкту. Визначення грошових параметрів проєкту в подальшому дослідженні дасть змогу провести оцінку ефективності проєкту ЕЛС.

\section{REFERENCES}

[1] A Guide to the Project Management Body of Knowledge (PMBoK) - Six Edition (2017) USA. PMI. 574 p.

[2] Kovtun, T.A. (2020) Frejmove modelyuvannya produktiv proektu ekologistichnoji sistemi // Rozvitok transportu. Nauk. zhurnal. no. 1(6). Pp. 17-29.

[3] Mezhdunarodnyj standart ISO 14001:2004 (2004) Sistemy ehkologicheskogo menedzhmenta. Trebovaniya i rukovodstvo po primeneniyu. 30 p. [in Russian]

[4] GOST R ISO/MEHK 12207-2010. Nacional'nyj standart RF. Processy zhiznennogo cikla programmnykh sredstv (2010) M. 188 p. [in Russian]

[5] GOST R ISO 14044-2019. Nacional'nyj standart RF. Ehkologicheskij menedzhment. Ocenka zhiznennogo cikla. Teoriya i trebovaniya (2019) M. 48 p. [in Russian]

[6] Kovtun, T.A. (2007) Metodicheskij podkhod k prinyatiyu upravlencheskikh reshenij po inicializacii produktov proekta transportnogo predpriyatiya. Upravlinnya proektami ta rozvitok virobnictva. № 2. Pp. 145-157. [in Russian]

[7] Onishchenko, S.P. (2009) Optimizaciya ob"ektnykh i vremennykh parametrov ehkspluatacionnoj fazy proektov razvitiya predpriyatij na primere sudokhodnykh kompanij. Metodi ta zasobi rozvitku transportnikh sistem. Zb. nauk. prac' ONMU. no. 15. Pp.70-84. [in Russian]

[8] Bernevek, T.I. (2018) Obosnovanie ob"ektnykh i vremennykh parametrov proektov popolneniya flota. Visnik ONMU. no.1 (54). Pp.175-186. [in Russian]

[9] Onishchenko, S.P., Arabadzhi, E.S. (2016) Razrabotka instrumentov upravleniya vremenem v ramkakh planirovaniya realizacii programmy razvitiya predpriyatiya. Tekhnologicheskij audit i rezervy proizvodstva. no. 2(3). Pp. 7-12. [in Russian]

[10] Ahsan, K., \& Gunawan, I. (2010) Analysis of cost and schedule performance of international development projects. International Journal of Project Management. no. 28(1). Pp. 68-78.

[11] Chang, C., Jiang, H.-y., Di, Y., Zhu, D., \& Ge, Y. (2008) Time-line based model for software project scheduling with genetic algorithms. Information and Software Technology. no. 50(11). Pp. 1142-1154.

[12] Herroelen, W., \& Leus, R. (2004) Robust and reactive project scheduling: a review and classification of procedures. International Journal of Production Research. no. 42(8). Pp. 1599-1620.

[13] Hyari, K., \& El-Rayes, K. (2006) Optimal planning and scheduling for repetitive construction projects. Journal of Management in Engineering. no. 22(1). Pp. 11-19.

[14] Cheng, M.-Y., and Tran, D.-H. (2014) Two-phase differential evolution for the multiobjective optimization of time-cost tradeoffs in resource constrained construction projects. IEEE Trans. Eng. Manage. no. 61(3). Pp. 450-461.

[15] Artigues, C., Michelon, P., \& Reusser, S. (2003) Insertion techniques for static and dynamic resource constrained project scheduling. European Journal of Operational Research. no.149(2). Pp. 249-267. 
[16] Cheng, M.-Y., Tran, D.-H., and Wu, Y.-W. (2014) Using a fuzzy clustering chaotic-based differential evolution with serial method to solve resource-constrained project scheduling problems. Autom. Constr. no. 37. Pp. 88-97.

[17] Baradaran, S., Fatemi Ghomi, S.M., Mobini, T.M., Hashemin, S.S. (2010) A hybrid scatter search approach for resourceconstrained project scheduling problem in PERT-type networks. Advances in Engineering Software. no. 41 (7-8). Pp. 966-975.

\section{СПИСОК ВИКОРИСТАНОӤ ЛІТЕРАТУРИ}

[1] A Guide to the Project Management Body of Knowledge (PMBoK) - Six Edition (2017) USA. PMI. 574 p.

[2] Ковтун Т.А. (2020) Фреймове моделювання продуктів проєкту екологістичної системи. Розвиток транспорту. Наук. журнал. Вип. 1(6). С. 17-29 [in Ukrainian].

[3] Международный стандарт ISO 14001:2004 (2004) Системы экологического менеджмента. Требования и руководство по применению. $30 \mathrm{c}$.

[4] ГОСТ Р ИСО/МЭК 12207-2010. Национальный стандарт РФ. Процессы жизненного цикла программных средств (2010) Москва, 188 с.

[5] ГОСТ Р ИСО 14044-2019. Национальный стандарт РФ. Экологический менеджмент. Оценка жизненного цикла. Теория и требования (2019) Москва, 48 с.

[6] Ковтун Т.А. (2007) Методический подход к принятию управленческих решений по инициализации продуктов проекта транспортного предприятия. Управління проектами та розвиток виробнищтва. № 2. С. 145-157.

[7] Онищенко С.П. (2009) Оптимизация объектных и временных параметров эксплуатационной фазы проектов развития предприятий на примере судоходных компаний. Методи та засоби розвитку транспортних систем. Зб. наук. праць ОНМУ. Вип. 15. С. 70-84.

[8] Берневек Т.И. (2018) Обоснование объектных и временных параметров проектов пополнения флота. Вісник ОНМУ. № 1 (54). С. 175-186.

[9] Онищенко С. П., Арабаджи Е.С. (2016) Разработка инструментов управления временем в рамках планирования реализации программы развития предприятия. Технологический аудит и резервы производства. № 2 (3). С. 7-12.

[10] Ahsan K., \& Gunawan I. (2010) Analysis of cost and schedule performance of international development projects. International Journal of Project Management. № 28 (1). P. 68-78.

[11] Chang C., Jiang H.-y., Di Y., Zhu D., \& Ge Y. (2008) Time-line based model for software project scheduling with genetic algorithms. Information and Software Technology. № 50 (11). P. 1142-1154.

[12] Herroelen, W., \& Leus, R. (2004) Robust and reactive project scheduling: a review and classification of procedures. International Journal of Production Research. № 42 (8). P. 1599-1620.

[13] Hyari K., \& El-Rayes K. (2006) Optimal planning and scheduling for repetitive construction projects. Journal of Management in Engineering. № 22 (1). C. 11-19.

[14] Cheng M.-Y., and Tran D.-H. (2014) Two-phase differential evolution for the multiobjective optimization of time-cost tradeoffs in resource constrained construction projects. IEEE Trans. Eng. Manage. № 61 (3). P. 450-461.

[15] Artigues C., Michelon P., \& Reusser S. (2003) Insertion techniques for static and dynamic resource constrained project scheduling. European Journal of Operational Research. № 149 (2). P. 249-267 .

[16] Cheng M.-Y., Tran D.-H., and Wu Y.-W. (2014) Using a fuzzy clustering chaotic-based differential evolution with serial method to solve resource-constrained project scheduling problems. Autom. Constr. № 37. P. 88-97.

[17] Baradaran S., Fatemi Ghomi S.M., Mobini T.M., Hashemin S.S. (2010) A hybrid scatter search approach for resourceconstrained project scheduling problem in PERT-type networks. Advances in Engineering Software. № 41 (7-8). P. 966-975. 